\title{
The Effect of Background Music on Translation Quality
}

\author{
Amin Karimnia \\ Islamic Azad University, Iran \\ Nastaran Sadeghzadeh Lari \\ Islamic Azad University, Iran
}

\section{Introduction}

Not for the first time the researchers have demonstrated the extraordinary effects of music on different areas. Beside the biological issues such as growing plants (Jun \& ShiRen, 2011), restfulness (Harmat, Taka'cs \& Bo'dizs, 2008), recalling memories (Mammarella, Fairfield \& Cornoldi, 2007) and brain function (Tyndall, 2004), music can affect those subjects which need concentration such as mathematics (Zhan, 2002), learning (Beckett, 2000) and painting quality (Waugh \& Riddoch, 2007) and since translation is considered not only as an art but also as an activity which needs concentration, this question may come to our mind if music can affect translation quality.

Although loud music can have negative effect on concentration, the value of classical music in producing soundness of mind in the hearers has been demonstrated in different researches (Tyndall, 2004).

Among all types of music, classical music has been selected in this study. Classical music is a kind of music often involving large orchestras and typically exists without vocal accompaniment. The instruments such as violins, flutes, clarinets, and pianos are used within this kind of music (Beckett, 2000).

Bach, Mozart, and Beethoven are some of the most recognizable and famous classical musicians but among these popular musicians the music of Mozart is the music of order. It induces order in the mind and an ordering of the emotions (Tyndall, 2004).

As it was mentioned briefly, a lot of studies have been done to show the effect of music on different areas but research that has investigated the effect of music on 
translation quality has gone somewhat unexplored. Therefore, the objective of this study was to examine the effect of classical music (Mozart) on translation quality.

\section{Review of Literature}

The peculiarity of classical music is that it affects the brain organization and abilities through its melody and rhythm. The rhythm increases the level of serotonin produced in the brain. But what is serotonin? It is a neurotransmitter, involved in the transmission of nerve impulses that helps maintaining joyous feelings. When the brain produces serotonin, tension is eased and depression decreased, because depression is the result of the scarce production of this hormone (Maglione, 2006).

Melody and rhythm are two necessary components of music. The right balance of rhythm and melody helps hens lay more eggs, cats to relax, and cows to produce more milk (Maglione, 2006).

Laurel Trainor, the director of the Institute for Music and the Mind at McMaster University in West Hamilton, Ontario, and colleagues had an investigation in which they had a comparison between preschool children who had taken music lesson with those who did not. It is demonstrated in their research that the children with musical training had larger brain responses on a number of sound recognition tests. According to this result, they came to this conclusion that musical training appears to change the brain's auditory cortex. Can larger claims be made for the influence on the brain of musical training? Does training change thinking or cognition in general? Trainor again says yes. He believed that even a year or two of music training causes increased levels of memory and attention when measured by the same type of tests that monitor electrical and magnetic impulses in the brain (Schewe, 2009).

In one research study, the effect of music on people who listened (or did not listen) to music during regular physical exercise has been taken into consideration by a clinical psychologist, Charles Emery, of Ohio State University. Emery says, "I have always thought that music had many benefits for people, and increasingly people use music when they exercise, so it seemed like a logical next step in terms of a research project". So along with Evana Hsiao and Scott Hill of Ohio State, and David Frid of Pfizer, Inc., Emery tested his theory with the help of 33 men and women in the final weeks of a cardiac rehabilitation program. The mental performance of each participant was examined after exercising with and without music. The results were surprising: on average, the performance of those who listened to music while exercising on a verbal fluency test was more than twice 
better than the performance of those who did not listen to music while exercising. The kind of music selected for this study was Vivaldi's "The Four Seasons". The reason why this music has chosen for consideration was that it helped patients with lung disease perform better mentally. Emery believes that when there was no music, there was no change ("Music for your brain health," 2008).

In order to find weather music could help in memorizing vocabulary words or not researchers from the University of North Texas performed a three-way test on postgraduate students in 1982. The students were divided into three groups. Each group was given three tests - a pretest, a post-test, and a test a week after the first two tests. All of the tests were identical. The music selected in this study was Handel's Water Music. Group 1 and 2 read the words while they were listening to music. The only difference between these two groups was that group 1 was asked to imagine the words. Group 3 only read the book without any exposure to music and without imagining the words. The results from the pretest and the post-test showed that groups 1 and 2 had much better scores than group 3. The results from the third test, a week later, showed that group 1 performed much better than groups 2 or 3 . However, listening to music while learning does not necessarily guarantee recall. Music is a part of learning process and it can possibly improve it. (O’Donnell, 1999).

There was another study which investigates the effect of music on students' test scores. The music selected in this study was Mozart's Sonata for Two Piano's in D Major. The reason is that this type of music releases neurons in the brain and helps the body to relax. Therefore, in order to find the effectiveness of this kind of music the researchers divided the participants into three groups. Group 1 listened to Mozart music before taking an IQ test. Group 2 listened to a relaxation tape before taking their test and group 3 did not listen to any type of music before their test. The results showed that the first group had the highest score with an average of 119. The second group ended up with an average of 111, and the third group had the lowest score with an average of 110 (O’Donnell, 1999).

\section{Suggestopedia Theory}

As it was cited in O’Donnell's paper (1999), a famous Bulgarian psychologist, Dr. George Lozanov, demonstrated that the students could learn up to one half of the vocabulary and phrases for the whole school term (which amounts to almost 1,000 words or phrases) in one day. He used certain classical music from the baroque era in his system with around a 60 beats per minute pattern. Moreover, the average retention rate of his students was $92 \%$. He has proven that foreign languages can be 
learned with $85-100 \%$ efficiency in only thirty days. It was surprising that his students had a recall accuracy rate of almost $100 \%$ even after not reviewing the material for four years.

\section{Music and Math}

There are some pieces of evidences that show the effectiveness of music on math ability. It was demonstrated in lots of researches that the children who had musical training in their young age, they are more skillful in their math abilities. It is necessary to mention that certain aspects of music, but not music as a whole, affect mathematics abilities. According to a study published in the journal 'Nature' when groups of first graders were given music instruction that emphasized sequential skill development and musical games involving rhythm and pitch, after six months, the students scored significantly better in math than students in groups that received traditional music instruction (Zhan, 2002).

Although the above results show the effectiveness of music on mathematics, Cox (1981) reported that classical music used during relaxation therapy had no statistically significant effect on algebra scores. According to Moller (1980) there was no significant difference in math test scores among groups exposed to three conditions: no sound, white noise background, and background music.

\section{Music and Reading Comprehension Skills}

Peter Tze-Ming Chou in 2010 considered the effect of different types of background music on reading comprehension task. This research tried to answer two questions: 1 . Does listening to music affect the learner's concentration when they are doing a task such as reading? and 2. Is light classical music more distracting or less distracting than hip hop music during a reading comprehension task? In order to do this study, 133 medium-size college students from southern Taiwan were selected. The participants performed a reading comprehension task while they were exposed to light classical music, hip hop music and no music. It was demonstrated from this study that the music with a higher intensity is more distracting and has a greater effect on task performance and concentration.

This question may come to the reader's mind that does the effect of music relate to the culture? Or does everyone affect from just the music of his/her own culture or not? 
Of course not. Music is a common communication tool, a common language. Irrelevant what language you speak and what your nationality is, you can feel music. Irrelevant if you realize it or not, it affects you!!! ("Stress relief music," 2009).

\section{Iranian Researchers and the Effect of Music}

The effects of music also attract the Iranian researchers in different fields. In this section, the researchers list a brief explanation of those theses which considered the effect of music in Iran.

In the field of plant sciences an M.A. student considered the comparative effect of acoustic waves (music) on the seeds germination and the genesis of seedlings in angiosperms and gymnosperms. In this research the effect of continuous and noncontinuous music waves (with 8-hour intermittence) has been considered on the germination, growth and genesis of runner bean (dicotyledonous), sweet corn (monocotyledon), and Tehran pine (gymnosperm) up to one month after sowing the seeds and they were compared with the control group. The results showed that the runner beans (with exposure to continuous music) have germinated 25\% more than the others and the germination of the sweet corn seeds (with exposure to noncontinuous music) and pine seeds (with exposure to continuous music) increased up to $40 \%$ and $200 \%$ respectively (Mohsennezhad, 2005).

Another research has been done in 2004 which showed the statistically significant effect of melodic and rhythmic music on visual and hearing attention of 8-12 yearold boys who were affected by ADD (Attention Deficit Disorder) (Moradi Ghadikolaee, 2004).

Nouri (2004) had a research in the field of psychology which considered the effect of two kinds of music (happy and sad) on painting quality of elementary school students. In order to do this research, the researcher selected 200 students randomly from 2 elementary school of Tehran. Half of them were in experimental group and the other half in control group. It should be mentioned that both experimental and control groups involved 50 boys and 50 girls. Besides the pretest which was equal for all, the students were asked to paint two times (post test): the first time with exposure to sad music and the second time with exposure to happy music. The post test of control group was done without any kind of music. Finally it was demonstrated that this research was statistically significant and the hypothesis was accepted. The researcher concluded that using sad and happy music affect the quantity of using cold and warm color and the quality of painting. 
The effect of music was also considered in the field of English teaching. In 2006 a student of Shiraz Azad University has done a research entitled "The Effect of a Quiet Environment, Noise and Music on Silent Reading”. In order to do this research, the researcher selected 40 female EFL child learners. These 40 learners participated in 4 tests under 3 different conditions: quietness, music (Mozart) and noise. T-test and Bonferroni test have been done in order to analyze and compare the scores of different conditions. The results of this study showed that certain type of music, especially Mozart is beneficial in reading situations (Shahsavar, 2006).

\section{The Long-Term Effect of Mozart on the Brain}

The long-term effect of music were compared between a group of pre-school children aged 3-4 years who were given keyboard music lessons for six months (group 1) and the children of similar age given either computer lessons for 6 months or no special training (group 2). At the end of training all the children in group 1 were able to perform simple melodies by Beethoven and Mozart. When they did they were then subjected to spatial-temporal reasoning tests calibrated for age, and their performance was more than $30 \%$ better than group $2(\mathrm{P}<0.001)$. The improvement was limited to spatial-temporal reasoning; there was no effect on spatial recognition. It was surprising that the effect lasted unchanged for 24 hours after the end of the music lessons but the precise duration of the enhancement was not further explored. One point should be mentioned that the longer duration of the effects than in previous reports was attributed to the length of exposure to music and the greater plasticity of the young brain (Graziano, Peterson \& Shaw, 1999).

Regarding these pieces of evidence, the effects of music, almost always classical music, could not be denied. Researchers have shown that music can affect not only an art but also those subjects which relates to concentration and imagination. One point which should be taken into consideration in this study is that the type of text selected to be given to the university students for translation is literary text and since literary translation is considered as an art (Xiaoshu \& Dongming, 2003), it can be hypothesize that whether classical music can affect translation quality or not?

\section{Research Question}

The present study seeks to answer the following question:

Are there any significant differences between students' translations when they are exposed to music (Mozart) and when they are not? 


\section{Methodology}

\section{Materials}

Since the participants were asked to participate in two tests (pretest and post-test), two different paragraphs of literary texts were given to them. The paragraphs were extracted from the book "The Memoirs of Georgio De Chirico" written by Georgio de Chirico (1994). The researchers tried to select those paragraphs which involved the factors mentioned in the assessment sheet. These factors are explained later in detail. The source texts were in English. So, the quality assessment of the students' translations from English into Persian with and without music was taken into consideration in this study.

\section{Participants}

In order to examine the effect of background music on the students' English-intoPersian translation quality, the researchers chose a total of 90 students randomly. The participants were selected from junior and senior B.A. students of translation studying at the Islamic Azad University, Shiraz, Iran. The students' mother tongue was Persian.

\section{Instruments}

In order to do this quantitative study, the researchers used different kinds of instruments.

Music was the first instrument used in this research. The kind of music chosen by the researchers was the classical music. From among the classical musicians the researchers selected the music composed by Mozart. The purpose of selecting Mozart was because it has been the subject of a lot of research in recent years and as it was mentioned in review of literature, it affected different sciences.

1. The first track was piano concerto No. 20 in D minor, K466-II. Romance, lasted 8 minutes and 43 seconds.

2. The second one was concerto for horn and orchestra No. 2 in E flat major, K417; III, Rondo; Allegro lasted 4 minutes and 7 seconds.

3. And the third one was clarinet concerto No.9 adagio in A major; K622 lasted 7 minutes and 22 seconds.

The other instrument which was adopted for data collection of this research was a questionnaire. The questionnaire consisted of ten questions, three of which were 
multiple-choice and the rest were open-ended in form. The questions about the students' favorite music, their opinion about translating while listening to music, their interest and skills in which kinds of text, their familiarity with literary text and so on were asked in the questionnaire.

The quality assessment of students' translations for both groups, with and without exposure to music, was measured by the quality assessment method which Hubscher-Davidson (2009) used in a research entitled "Personal Diversity and Diverse Personalities in Translation". This was another instrument which the researchers applied for data collection.

The mentioned scale is designed to assess seven factors which are the most important factors in translation. These factors are as follows:

- $\quad$ Stylistic features e.g. register

- Vocabulary

- Grammar

- $\quad$ Idioms

- $\quad$ Cultural features

- Imagery/expressions

- $\quad$ Overall coherence of translation

The students' translations were rated on the scale from 1 (very poor) to 5 (excellent) (Appendix E). After that the researchers calculated the scores, the marks were reported out of 100 .

\section{Design and Procedure}

This study used a causal comparative approach. The independent variable is background classical music and the dependant one is the scores the students obtain for their translations on the rating scale.

The participants in the study were B.A. junior and senior students majoring in Translation at Islamic Azad University, Shiraz Branch. The researchers selected those students who had passed "Translation Principles" and "Translation Theories". The quality of their translations was examined in a pretest and a post test.

In order to do the pretest (Appendix A), the researchers randomly chose different translation classes held in the first term of 2010-2011 academic year and asked 90 students to translate the given paragraph into Persian. The pretest involved a 
paragraph in literary type which was extracted from Georgio de Chirico (1994). The researchers provided a glossary for the students. The purpose of providing this glossary was that the students would have accessed to the same information and the same meaning for each vocabulary which was guessed to be hard for the students. The meanings of the hard vocabularies were extracted from the Millennium English-into-Persian Dictionary (2005). The purpose of the pretest was that the researchers would homogenize the students for the post-test. It means, with the help of the pretest, the researchers could select those students whose scores and consequently their knowledge of translation were in the same range.

One point should be mentioned that the researchers used the timing procedure in the pretest. It means that the researchers did not determine any specific time for translation in the pretest, but the researchers wrote down on the top of each sheet the time every student spent on translation. The researchers then calculated the mean of the total times in order to use it in the post-test.

The researchers provided three series of the tests in order to give them to three raters. The raters were asked to mark the students' translations in the assessment sheets attached to the papers. The raters were three experts who held an M.A. in the field of English language and had the experience and the knowledge of assessing students' translations. The raters then scored the students' translations according to the criteria of assessment sheets individually. From among the seven factors mentioned in the assessment sheet the text of the pretest supported all factors except "idiom" and "cultural feature". So, the raters were asked to consider only those criteria that could be applied to the texts for the process of assessment. After the translations having been rated the researchers had three scores for each translation. So the mean of these three scores for each translation was calculated. It was the time for the researchers to select those who were appropriate for the posttest. For this purpose from among 90 scores the researchers chose 58 scores between 50-75 and omitted those lower than 50 and higher than 75 and divided them into two control and experimental groups so that the means of the scores in each group became identical.

The post-tests of both groups were held in the English laboratory of Shiraz Azad University. As compared with the classrooms, the laboratory was a place in which less noise disturbs the students' concentration. The other advantage of laboratory was that the students of the experimental group could listen to music through headphones. It should be mentioned that each group included 29 students. The control group consisted of the students who translated the text without any exposure to music but the experimental group was those who translated the text with exposure to Mozart music. 
The post-test (Appendix B) also involved a paragraph in literary type extracted from the same book. It was not permissible for the students to use any kinds of dictionary in the post-test, either. The meanings of the vocabularies were written in a glossary (Appendix C) which was attached to each sheet.

As it was mentioned before, the researchers used the timing procedure in the pretest and calculated the mean of the times which take for each student to translate the text. The mean was 20 minutes. The researchers used this time for the post-test because when the researchers wanted to select the paragraphs of the pretest and the post-test, their ease of reading was examined. Therefore, the researchers could use the mean times of the pretest for the post-test. It means that the students should translate the text of the post-test in just 20 minutes, not more and not less.

The researchers tried to hold both tests under the same circumstances. The only difference of the experimental and the control group was that the experimental group translated the text with exposure to music and they were asked to answer the questions of a questionnaire carefully and wrote the reasons where necessary.

In order for the students not to aware of the purpose of the study, the researchers gave the questionnaire (Appendix D) to the students after they finish their translating.

As it was mentioned, the experimental group translated the text with exposure to music of Mozart. From among all music of Mozart the researchers should choose the music which causes the feeling of comfort and security in the hearers. The music should not disturb the hearers' concentration. Therefore, the researchers chose three tracks. They were selected from those tracks of Mozart music which have been used for music therapy in Shiraz Hafez hospital. It was demonstrated that those patients who listened to the following music felt comfort. The patients were exposed to the music of Mozart and at that moment the level of serotonin produced in their brain was measured. Since serotonin is the neurotransmitter which eases tension and causes relaxation (Maglione, 2006), when it increases in the brain it can be concluded that the patient feels comfort and relax. The researchers also listened to the following music and their relaxing effect has proven for her, too.

After the exam, the post-test also followed those procedures done in the pretest. So, the sheets were given to three raters in order to score the students' translations according to the criteria of assessment sheets individually. The raters of pretest and post-test were the same. To control for the raters' bias, the researchers tried to select those raters who were not aware of the aims of the study or context. Another strategy the researchers employed in order for scores not to be subjective was that 
the translation sheets were arranged in odd and even numbers. Those translations which had been done without exposure to music had odd numbers and the translation sheets with even numbers belonged to those who translated the text with exposure to music. None of the raters knew about this strategy. In this way even if one of the raters heard about the aim of the study before, he/she could not determine whether the translation under evaluation had been produced with or without exposure to music.

The rationale for using these raters was motivated by the wish to render the analysis more objective and realistic than if it had been conducted by the researchers, whose knowledge of the study's aims could have influenced the analytical process.

After assessing the translations, the researchers calculated the mean of the three scores for each translation. At this time the researchers had one score for each participant in each group. Thus the researchers obtained the mean score of the control and the experimental group separately. This mean score became the criterion in comparing the experimental and control groups.

\section{Data Analysis Procedure}

In order to find the effect of music on English-into-Persian translation quality the researchers employed an independent sample t-test to see the mean difference of control and experimental groups. For this purpose, an analytical statistical package of SPSS, version 18, has been used by the researchers. But before the tables and the results are explained, the researchers mention some points extracted from the questionnaire.

\section{Results}

The researchers gathered the questionnaires, analyzed the answers and showed them in percent as follows:

First of all the researchers asked the students some general questions about music.

1. It is demonstrated that $58 \%$ of the students liked classical music, $62 \%$ of them liked pop music and none of them liked rock music. 
2. $68 \%$ of the participants did not prefer to study while listening to their favorite music. In their opinion listening to music causes them not to concentrate. They preferred the quiet environment because they believed that when they listen to music they concentrate on the music rather than studying. However, $24 \%$ of them agreed with this method. It means that they preferred to listen to music while studying. But the kind of music they preferred was classical music, the nonverbal music and the music which causes the feeling of comfort in the hearers. In their opinion, this kind of music made them to concentrate better, understand the text more, forget their stress and not to tired of studying. It is necessary to mention that there was one abstention among the participants. He/she stated that it is not different for him/her to listen or not to listen to music while studying. Another participant believed that it the effectiveness of music depends on the kind of lessons. If the lesson should be memorized, the music has negative effect but if it should be understood, a classical or calm music can be effective.

3. The students also have different opinions in answering to the question that "have you ever listened to music while translating or not?"

The answer of $58 \%$ of them was No. it means that they did not examine such condition just because they believed that translating is a work which needs a quiet environment and because of this belief they did not exposed themselves in such condition. On the contrary, $41 \%$ of the participants examined such situation. They believed that not only they did not feel tired while listening to music, but also they feel comfort. In their opinion they can concentrate better on the text while they listen to music. Moreover, music can help them to select more suitable equivalent for each vocabulary.

After that the researchers asked them some questions about the music which they listened while translating.

4. It was interesting that the majority of the students (75\%) liked this kind of music because in their opinion it was a calm music and they felt comfort. They stated that they can concentrate more. When this percent compared with the previous percentages it can be concluded that even those who did not agree with the method of translating or studying while listening to music, they agreed with this kind of music.

It should be mentioned that just $17 \%$ of them did not prefer this kind of music while translating and there were two abstentions among the participants (they stated that music has no effect on them. It was neither distracting nor comforting). 
5. In another question the researchers asked the students whether this music could enhance your power of imagination or not?

$53 \%$ of the students stated that this music enhanced their power of imagination. They wrote that music and literary texts depend upon each other. Some of them mentioned that the selected music and the text were similar to each other and the others told that their sentence making changed with listening to this kind of music.

$34 \%$ of them had the adverse idea. They mentioned that music distracts them, the selected music and text were different from each other and some of them stated that they had such concentration on the text as if they did not hear the music.

This question had also two abstentions. They believed that the text was imaginable even without music. Music had no effect on their power of imagination.

The rest of questions related to the students' opinion and familiarity with translating literary texts.

6. $30 \%$ of the participants were not familiar with literary texts translations and the rest of them knew it to the extent of university credits and just a few of them had translated such texts beyond the university credits.

7. $70 \%$ of them did not pass the credit of "translating literary text" and only $30 \%$ of them passed it in the university.

8. The majority of students believed that they can translate non-literary texts better than literary ones because they have translated non-literary texts more than the literary ones up to now. In their opinions, the texts such as scientific, narrative and so on are simpler than literary texts and they do not need the power of imagination and feeling.

\section{Basic statistics}

After the scores and the mean scores of the experimental and the control group prepared, the researchers arranged them into two different tables.

Table 1 and 2 drawn in the next two pages show the raw data and their related means out of 100 . Table 1 demonstrates the scores given by three raters for those without exposure to music and Table 2 shows the scores given by three raters for those with exposure to music. 
Table 1: Percentage Scores Given by the Three Raters for Those WITHOUT Exposure to Music

\begin{tabular}{|c|c|c|c|c|}
\hline Students & Rater 1 & Rater 2 & Rater 3 & Average \\
\hline$S_{1}$ & 40 & 92 & 44 & 58.66 \\
\hline $\mathbf{S}_{2}$ & 24 & 56 & 24 & 34.66 \\
\hline $\mathrm{S}_{3}$ & 32 & 68 & 32 & 44 \\
\hline $\mathrm{S}_{4}$ & 32 & 52 & 32 & 38.66 \\
\hline$S_{5}$ & 56 & 76 & 64 & 65.33 \\
\hline$S_{6}$ & 32 & 76 & 32 & 46.66 \\
\hline $\mathrm{S}_{7}$ & 40 & 68 & 64 & 57.33 \\
\hline$S_{8}$ & 48 & 76 & 32 & 52 \\
\hline$S_{9}$ & 52 & 76 & 32 & 53.33 \\
\hline$S_{10}$ & 32 & 64 & 24 & 40 \\
\hline$S_{11}$ & 32 & 64 & 36 & 44 \\
\hline$S_{12}$ & 44 & 80 & 36 & 53.33 \\
\hline $\mathrm{S}_{13}$ & 40 & 72 & 40 & 50.66 \\
\hline$S_{14}$ & 32 & 76 & 36 & 48 \\
\hline$S_{15}$ & 36 & 76 & 56 & 56 \\
\hline$S_{16}$ & 56 & 56 & 36 & 49.33 \\
\hline$S_{17}$ & 60 & 72 & 64 & 65.33 \\
\hline$S_{18}$ & 76 & 64 & 24 & 54.66 \\
\hline $\mathrm{S}_{19}$ & 52 & 60 & 28 & 46.66 \\
\hline $\mathbf{S}_{20}$ & 36 & 64 & 32 & 44 \\
\hline
\end{tabular}




\begin{tabular}{|c|c|c|c|c|}
\hline $\mathbf{S}_{21}$ & 56 & 72 & 28 & 52 \\
\hline $\mathbf{S}_{22}$ & 68 & 68 & 44 & 60 \\
\hline $\mathbf{S}_{23}$ & 52 & 60 & 32 & 48 \\
\hline $\mathbf{S}_{24}$ & 36 & 68 & 60 & 54.66 \\
\hline $\mathbf{S}_{25}$ & 60 & 72 & 60 & 64 \\
\hline $\mathbf{S}_{26}$ & 68 & 76 & 32 & 58.66 \\
\hline $\mathbf{S}_{27}$ & 52 & 80 & 32 & 54.66 \\
\hline$S_{28}$ & 52 & 88 & 44 & 61.33 \\
\hline$S_{29}$ & 56 & 76 & 52 & 61.33 \\
\hline Average & 46.62069 & 70.62069 & 39.724138 & 52.318621 \\
\hline
\end{tabular}

S: Student

Table 2.: Percentage Scores Given by the Three Raters for those WITH Exposure to Music

\begin{tabular}{|r|r|r|r|r|}
\hline Students & Rater 1 & Rater 2 & Rater 3 & Average \\
\hline $\mathbf{S}_{\mathbf{1}}$ & 40 & 68 & 44 & 50.66 \\
\hline $\mathbf{S}_{\mathbf{2}}$ & 36 & 52 & 28 & 38.66 \\
\hline $\mathbf{S}_{\mathbf{3}}$ & 32 & 44 & 32 & 36 \\
\hline $\mathbf{S}_{\mathbf{4}}$ & 32 & 76 & 56 & 54.66 \\
\hline $\mathbf{S}_{\mathbf{5}}$ & 24 & 60 & 24 & 36 \\
\hline $\mathbf{S}_{\mathbf{6}}$ & 44 & 64 & 44 & 50.66 \\
\hline $\mathbf{S}_{\mathbf{7}}$ & 52 & 56 & 36 & 52 \\
\hline $\mathbf{S}_{\mathbf{8}}$ & 32 & 76 & 48 & \\
\hline
\end{tabular}


Amin Karimnia

\begin{tabular}{|c|c|c|c|c|}
\hline $\mathbf{S}_{9}$ & 32 & 72 & 40 & 48 \\
\hline$S_{10}$ & 56 & 60 & 44 & 53.33 \\
\hline $\mathbf{S}_{11}$ & 32 & 56 & 52 & 46.66 \\
\hline$S_{12}$ & 60 & 76 & 44 & 60 \\
\hline$S_{13}$ & 36 & 64 & 36 & 45.33 \\
\hline$S_{14}$ & 48 & 68 & 24 & 46.66 \\
\hline $\mathbf{S}_{15}$ & 36 & 64 & 36 & 45.33 \\
\hline$S_{16}$ & 64 & 76 & 40 & 60 \\
\hline$S_{17}$ & 36 & 64 & 40 & 46.66 \\
\hline$S_{18}$ & 56 & 64 & 40 & 53.33 \\
\hline$S_{19}$ & 56 & 60 & 36 & 50.66 \\
\hline$S_{20}$ & 36 & 56 & 24 & 38.66 \\
\hline$S_{21}$ & 56 & 72 & 32 & 53.33 \\
\hline $\mathbf{S}_{22}$ & 52 & 76 & 36 & 54.66 \\
\hline $\mathbf{S}_{23}$ & 32 & 52 & 36 & 40 \\
\hline $\mathbf{S}_{24}$ & 36 & 64 & 28 & 42.66 \\
\hline $\mathbf{S}_{25}$ & 52 & 76 & 28 & 52 \\
\hline $\mathbf{S}_{26}$ & 28 & 60 & 36 & 41.33 \\
\hline $\mathbf{S}_{27}$ & 52 & 68 & 60 & 60 \\
\hline $\mathbf{S}_{28}$ & 28 & 72 & 44 & 48 \\
\hline$S_{29}$ & 76 & 72 & 44 & 64 \\
\hline Average & 43.172414 & 65.103448 & 38.344828 & 48.870345 \\
\hline
\end{tabular}

S: Student 
As it is observed, the mean of the control group (52.3186) is more than the mean of the experimental group (48.8703). Therefore, an independent sample t-test has been done to see whether the difference between the means of these groups were significant or not.

\section{T-test Procedure}

Table 3: Descriptive Results of Comparing the Mean Scores of Control and Experimental Groups Group Statistics

\begin{tabular}{|r|r|r|r|r|r|}
\hline & group & $\mathrm{N}$ & Mean & Std. Deviation & $\begin{array}{r}\text { Std. } \\
\text { Error } \\
\text { Mean }\end{array}$ \\
\hline Average & Control & 29 & 52.3186 & 8.02897 & 1.49094 \\
& Experiment & 29 & 48.8703 & 7.34924 & 1.36472 \\
\hline
\end{tabular}

Table 4: Inferential Results of Comparing the Mean Scores of Control and Experimental Groups

\section{Independent Samples Test}

\begin{tabular}{|c|c|c|c|c|c|c|c|c|}
\hline & & \multicolumn{2}{|c|}{$\begin{array}{r}\text { Levene's Test } \\
\text { for Equality of } \\
\text { Variances }\end{array}$} & \multicolumn{5}{|c|}{ t-test for Equality of Means } \\
\hline & & I & $\ddot{\infty}$ & - & t & 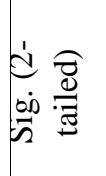 & 忢 & 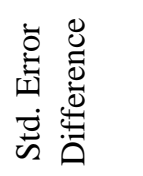 \\
\hline 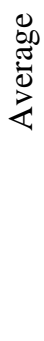 & 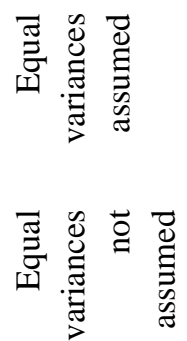 & .266 & .608 & 1.706 & 56 & .094 & 3.44828 & 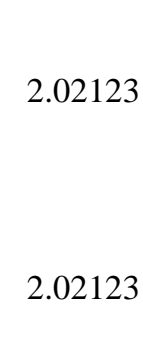 \\
\hline
\end{tabular}


Table 3 and 4 show the results of an investigation into the effect of music on translation quality. Regarding the significance value of Levene's test (0.608), the assumption of equal variances is accepted. The mean score of the students who translated the text while listening to music (48.8703) is less than the mean score of those who translated the text without any kind of music (52.3186) and since the observed difference between the quality of translation of two groups is not significant (Sig. $=0.094$ ) according to t-test value (1.7) and the level of confidence (95\%), the above hypothesis is not accepted. It means, though the mean score of the students who translated with exposure to music is less than the mean score of those who translated without exposure to music, the results cannot be generalized. Therefore, based upon the statistical analysis background music has no effect on translation quality.

\section{Discussion}

As it was cited in O'Donnell's (1999) paper, Dr. Lozanov used classical music to help the students learn up to one half of the vocabulary and phrases for the whole school term in one day.

Researchers from the University of North Texas used Handel's Water Music (classical music) to see if music could help in memorizing vocabulary words. They demonstrated that those who listened to this type of music had much better scores (O’Donnell, 1999).

Despite the above results, there have been several studies that indicate that although classical music is helpful for memorizing, it is not as helpful for mental concentration and or test-taking. A research study found that the test subjects performed mental tasks more effectively without any music as compared to classical music. Another study confirmed the above results and found that classical music had a negative impact on students taking math exams (Beckett, 2000).

One particular study published in the journal 'Nature' showed that when groups of first graders were given music instruction the students scored significantly better in math than students in groups that received traditional music instruction (Zhan, 2002).

Although the above result shows the effect of music on mathematics, Cox (1981) reported that classical music used during relaxation therapy had no statistically significant effect on algebra scores. Moller (1980) found no significant difference in math test scores. 
Peter Tze-Ming Chou in 2010 showed that the music with higher intensity (e.g. hip hop music) is more distracting than the music with lower intensity (e.g. light classical music) and the environment with lower intensity has a greater effect on task performance and concentration than an environment with no music but according to Shahsavar (2006) certain type of music, especially Mozart is beneficial in reading situations.

According to the above study, it can be concluded that although some study could demonstrate the beneficial effects of music on memorizing, learning, math scores and reading comprehension skills, other researchers found no significant effect of classical music on the mentioned fields.

In spite of all of these contradictions, the researchers of the present study employed similar methods to investigate the effect of classical music in the field of translation.

Although it is demonstrated that the difference of two mean scores was not significant and the results cannot be generalized, the data collected from the questionnaire shows something other than this result. It means, though music could not practically affect the quality of students' translations, the participants opinion after listening to the selected music did not support this result.

According to the data collected from the questionnaire more than half of the students have not ever translated while listening to music because they believed that translating is a work which needs concentration and this concentration would not be attained unless in a quiet environment. Because of this belief they never exposed themselves in such condition. They considered music as a distracting tool which draws their attention to listening to it rather than concentrating on the text.

But their comments have not logical basis. In fact they just thought that music can be distracting because when they were asked to write their opinion about the selected music, the majority of them (75\%) liked this kind of music. In their opinion it was a calm music and they felt comfort and concentrate more. It means that even those who did not prefer to translate while listening to music, agreed with this kind of music. They have never examined such situation, may be because they were not aware of the surprising effects of music or they were always told that translating should be done in a quiet environment!

Moreover, $70 \%$ of the students did not pass the credit of "Literary Text Translation" and only $30 \%$ of them passed it in the university. Also $30 \%$ of the participants were not familiar with literary texts translations and the rest of them knew it to the extent of university credits and just a few of them had the experience 
of translating such texts beyond the university credits. Therefore, the result of this study might be changed if the participants had the skill of translating literary texts or if at least all of them had passed the credit of "Literary Text Translations" in the university.

\section{Conclusion}

According to the data collected from the questionnaire in which the students' opinion changed after listening to the music of Mozart while translating although the statistical analysis of this research shows that translating without exposure to music could have better quality, the researchers can come to this conclusion that if the students were taught scientifically to listen to such music while translating, if they had the experience of translating while listening to music before and if they were aware of the surprising effects of music on the mind and concentration, music could show its effect on the quality of students' translations in another way.

If the students had the experience of translating while listening to music before, the result of this study might change because some of the students stated in their questionnaire that they found music as a distracting tool at the few first moments which they heard it and they had not good feeling but they soon got used to it.

This research showed that music had no effect on the quality of the students' translations but since the difference between the mean score of the control and the experimental group was not a lot and the tests of both groups have been done in English language laboratory in which less noise is heard because of its structure and also regarding the fact that the students' opinion changed after listening to music while translating, it can be also concluded that music may be effective at reducing acoustic pollutions in the environment because according to Acoustical Society of America (2000) complete quietness is nearly impossible to achieve since the sounds of construction and other natural and artificial environmental noises invade almost every aspect of the life. Anyone who starts to translate a text in the home, in translation centers and even in classrooms cannot get rid of the harmful noises around him/her.

\section{Pedagogical Implications}

According to the data collected from the questionnaire of this study, the students preferred to translate in a quiet environment but as it was mentioned in detail earlier, complete quietness cannot be achieved and no one could get rid of the harmful and distracting effect of noise in the environment. Therefore, the effect of 
certain type of music, especially Mozart, can be beneficial in reducing the environmental noises and also enhancing concentration and the feeling of comfort and security.

If we would intend to observe the effect of music on translating, the researchers suggest that the surprising effect of music almost always classical music should be obvious for everyone. For this purpose, first of all the teachers should be trained. These are the teachers who can introduce the effective music to the students and teach them how to use music so that it does not draw their attention to itself. The students should be taught to cover up some of the distractions by the help of music, not to consider it as a tool which causes distraction.

Music can be effective for those whose work is translating and they have to translate 8 to 10 hours every day, it is effective for those who work in translation centers where they have to sit on a chair hours and type and translate the text simultaneously. Music can not only eliminate their tiredness, but also it can increase their productivity.

\section{References and Notes:}

Acoustical Society of America (2000). Classroom acoustics booklet: NY 11747.

Beckett, G. (2000). Effects of classical music on concentration. Retrieved December 17, 2010 from http://www.ehow.com/about_5495318_effects-classical-musicconcentration.html.

Chou, P. T. (2010). Attention drainage effect: How background music effects concentration in Taiwanese college students. Journal of the Scholarship of Teaching and Learning, 10, 36 - 46.

Cox, M. O. (1981). Effects of hypnotherapy and relaxation training on mathematics achievement. Doctoral Dissertation. A \& M University: Texas.

DeChirico, G. (1994). The memoirs of Georgio DeChirico (pp. 14 \& 47). NewYork: Dacapo Press.

Graziano, A. B., Peterson, M. \& Shaw, G. L. (1999). Enhanced learning of proportional maths through music training and spatial-temporal reasoning. Neurol Res, 21, 139152.

Haghshenas, A., Samei, H. \& Entekhabi, N. (2005). Millennium English-into-Persian dictionary (15 ${ }^{\text {th }}$ ed.). Iran: Farhang-e-Moaser Press.

Harmat, L., Taka'cs, J. \& Bo'dizs, R. (2008, May). Music improves sleep quality in students. J Adv Nurs, 62, 327-35.

Hubscher-Davidson, S. E. (2009, September). Personal diversity and diverse personalities in translation: A study of individual differences. Perspectives: Studies in translatology, 17, 175-192.

Jun, H. \& ShiRen, J. (2011). Effect of six different acoustic frequencies on growth of cowpea during its seedling stage. Agricultural Science \& Technology - Hunan, 12, 847-851. 
Maglione, S. F. (2006, March 2). Effect of classical music on the brain. Retrieved December 18, 2010 from http://www.classicalforums.com/articles/Music_Brain.html.

Mammarella, N., Fairfield, B. \& Cornoldi, C. (2007, October). Does music enhance cognitive performance in healthy older adults? The Vivaldi effect. Aging Clin Exp Res, 19, 394-9.

Mohsennezhad, S. (2005). An investigation into the comparative effect of acoustic waves (music) on the seeds germination and the genesis of seedlings in angiosperms and gymnosperms. Unpublished master's thesis, Islamic Azad University, Tehran, Iran.

Moller, L. E. (1980). Performance of musicians under noise. Perceptual and Motor Skills, 50, 301-302.

Moradi Ghadikolaee, K. (2004). An investigation into the effect of melodic and rhythmic music on visual and hearing attention of 8-12 year-old boys who were affected by $A D D$ (Attention Deficit Disorder). Unpublished master's thesis, Islamic Azad University, Tehran, Iran.

Music for your brain health? (2008). Retrieved December 18, 2010 from http://www.brainready.com/blog/music_for_your_brain_health.html.

Nouri, Z. (2004). An investigation into the effect of two kinds of music (happy and sad) on painting quality of elementary school students. Unpublished master's thesis, Islamic Azad University, Roodehen, Iran.

O’Donnell, L. (1999). Music and the brain. Retrieved December 22, 2010 from http://www.cerebromente.org.br/n15/mente/musica.html.

Schewe, P. F. (2009, November 06). Music improves brain function. Retrieved December 22, 2010 from http://www.livescience.com/7950-music-improves-brainfunction.html.

Shahsavar, Z. (2006). The effect of a quiet environment, noise \& music on silent reading. Unpublished master's thesis, Islamic Azad University, Shiraz, Iran.

Stress relief music, (2009). Retrieved December 17, 2010 from http://www.stressmanagement-for-health.com/stress-relief-music.html.

Tyndall, J. (2004, September 20). Music of the west: Classical music enhances brain function. Retrieved December 18, 2010 from http://forums.skadi.net/showthread.php?t=69299.

Waugh, R. F. \& Riddoch, J. V. (2007). The effect of classical music on painting quality and classroom behaviour for students with severe intellectual disabilities in special schools. International Journal of Special Education, 22, 2-13.

Xiaoshu, S. \& Dongming, C. (2003, January). Translation of literary style. Translation Journal, 7.

Zhan, C. (2002). The correlation between music and math: A neurobiology perspective. Retrieved December 22, 2010 from http://serendip.brynmawr.edu/exchange/node/1869. 


\title{
yrammuS
}

\section{The Effect of Background Music on Translation Quality}

\author{
Amin Karimnia \\ Islamic Azad University, Iran \\ Nastaran Sadeghzadeh Lari \\ Islamic Azad University, Iran
}

The current study was designed to investigate the effect of background classical music of Mozart on the students' English-into-Persian translation quality. To achieve this purpose, at first 90 B. A. junior and senior students majoring in Translation were selected randomly from Islamic Azad University, Shiraz, Iran. These 90 students participated in a translation pretest. The pretests were assessed and the researchers chose 58 ones whose scores in the pretest were in the same range. These 58 students were then divided into an experimental and a control group, each of which having 29 students. They were asked to participate in the post-test. The experimental group involved the students who translated the text with exposure to music and the control group consisted of those who translated without exposure to music. The post-tests were also assessed and the mean scores of the experimental and the control groups were then calculated. An independent sample t-test was employed in order to find whether the difference between the means of the experimental and control group was significant or not. Finally, it was demonstrated that background music had no effect on the students' translation quality.

Key Words: background music, classical music, Mozart, translation. 
Pretest

Name:

Year of Matriculation:
Appendix (A):

\section{Student No.:}

Cell Phone No.:

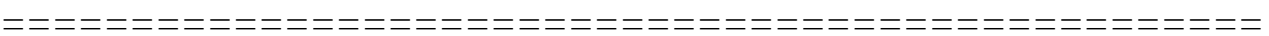

\section{* Please translate this English passage into its equal Persian.}

Entering, I saw first my mother and my brother, both of them sobbing; I rushed to the bed where my father lay, and he seemed to me peaceful, his eyes closed and a serene expression upon his face, almost happy, like someone who, tired from a long and arduous journey, had finally found repose in sweet, deep sleep.

From: Memoirs, by: Georgio de Chirico

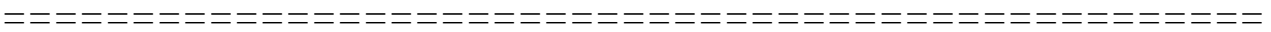

Sob: هق هق كردن، هق هق كريه كردن

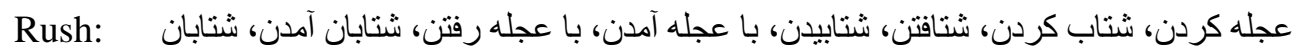

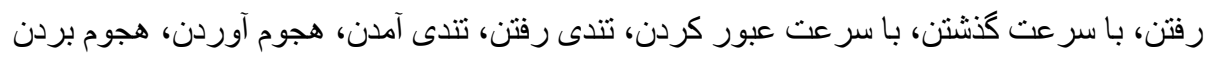

Serene: آر ام، ساكت

Expression: بيان، اظهار، ابراز، نمود، نمايش، عبارت، اصطلاح، تعبير، حالت، لحن

Arduous: سخت، دشوار، شاق، طاقت فرسا، بِر فر از و نشيب

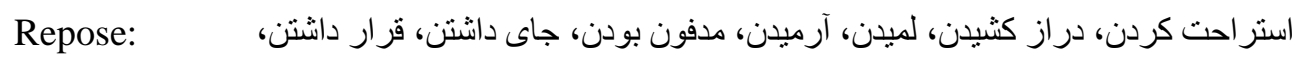

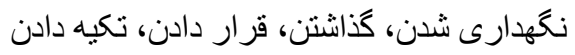




\section{Appendix (B):}

\section{Posttest}

Name:

\section{Student No.:}

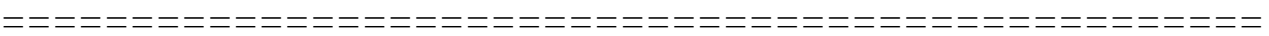

\section{Please translate this English passage into its equal Persian.}

I remember an enormous mechanical butterfly that my father had brought me from Paris when I was recovering from an illness. I would look at that toy from my bed at once fascinated and afraid, just as the first humans must have looked at the giant pterodactyl as it flew heavily on fleshy wings through sultry twilights and frozen dawns over blasts of sulfurous vapor erupting from hot, bubbling lakes.

From: Memoirs, by: Georgio de Chirico

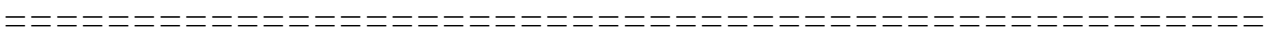


Appendix (C):

\section{The Glossary of Posttest}

Enormous: بزرگ، عظيم، عظيم الجثه، غول آسا، زياد، فراو ان، كلان، هنكفت

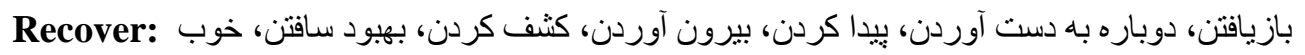

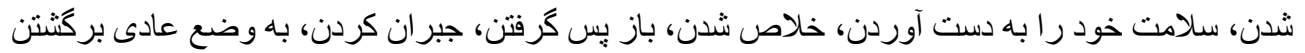

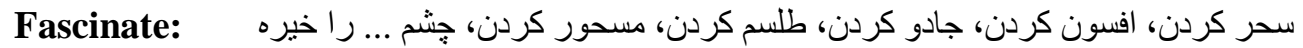

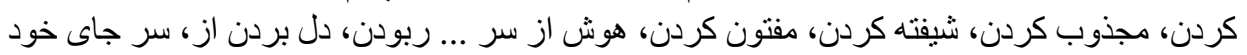

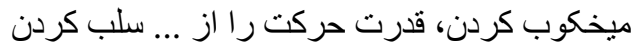

Giant: غول آسا، غول بيكر ، عظيم الجثه، عظيم، خيلى بزرت

Pterodactyl: يتروداكتيل (= نوعى خزنده ى بالدار ماقبل تاريخ)

Heavily: به شدت، سخت، حسابى، خيلى، زياد، به سختى، به زحمت، با دشو ارى

Fleshy: كوشت دار، كُشتنالو، جِاق، كُشتى، كَشت مانند

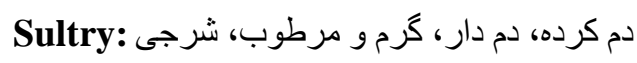

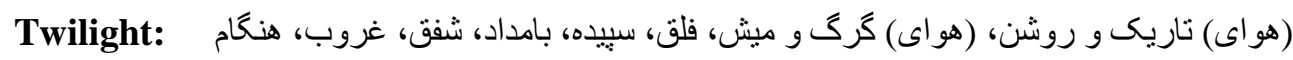

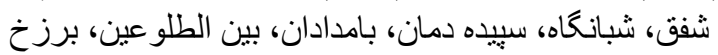

Dawn: سبيده دم، بحاه، سحر، فجر، طليعه، سر آغاز ، بيدايش، ظهور

Blast: جريان، وزش، طوفان، موج انفجار، دم، دمش، (انفجار ) صدا، غرش

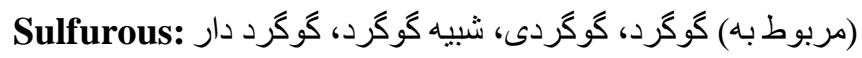

Vapor: بخار، احساس ضعف، احساس غش، حمله عى عصبى، خود بيمار انكارى

Erupt: فوران كردن، طغيان كردن، دهان باز كردن، بيرون ريختن، بيرون زدن، نيش زدن، در آمدن

مباب، خيال و اهى، وهم، سر اب، جوش، كاز ، قل قل : 


\section{Questionnaire}

\section{Appendix (D):}

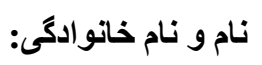

لطفاً به سوالات زع با دقت و صادقاته ياستخ دهيد.

$$
\text { 1 }
$$

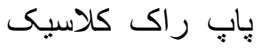

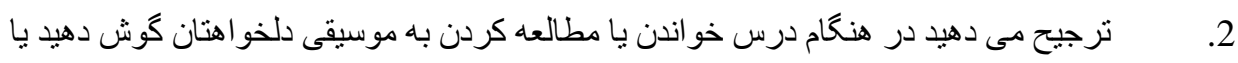
خير؟ با ذكر دليل. (اكر جو اب مثبت است ذكر نوع موسيقى الز امى است.)

$$
\text { 3. آيا تاكنون در هنگام ترجمه كردن به موسيقى كوش داده ايد؟ جر ا؟ }
$$

$$
\text { 4. در مورد موسيقى اى كه يخش شد جهه احساسى داريد؟ }
$$

$$
\text { 5. }
$$

6. آيا مو سيقى بخش شده نوانست قدرت تصويريردازى و تخيل شما را در ترجمه افز ايش دهد؟ با ذكر دليل. 
7. آيا با ترجمه ى متون ادبى آثنايى داريد؟ نوضيح دهيد.

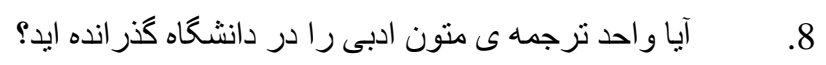

9.

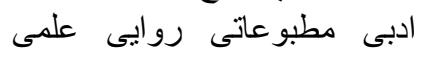

10. تاكنون جهه نوع متنى را بيشتر نرجمه كرده ايد؟ جه مدت؟

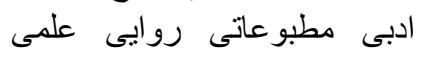




\section{Appendix (E):}

\section{Marker's Assessment Sheet}

On a scale from 1 (very poor) to 5 (excellent), please rate how you felt this student handled the following aspects in his/her translation:

\begin{tabular}{|c|c|c|c|c|c|}
\hline & & 2 & 3 & 4 & 5 \\
\hline & Stylistic features e.g. register & & & & \\
\hline 2 & Vocabulary & & & & \\
\hline 3 & Grammar & & & & \\
\hline 4 & Idioms & & & & \\
\hline 5 & Cultural features & & & & \\
\hline 6 & Imagery/expressions & & & & \\
\hline 7 & Overall coherence of translation & & & & \\
\hline
\end{tabular}

What mark (out of 100) would you give the student for this translation?

Other comments: 